\title{
Legal Protection of Witnesses and Reporters in Revealing Narcotics Case by Pekanbaru City Police Resort
}

\section{Khairani Miftahul Jannah*}

University of Riau, Pekanbaru, Indonesia

* khairanimiftahuljannah@gmail.com

\begin{tabular}{l}
\hline Article Info \\
\hline Received : 2020-06-29 \\
Accepted : 2021-03-04 \\
Published : 2021-03-05 \\
\hline
\end{tabular}

Key words: protection, law, Abstract witness, reporter

\begin{abstract}
Human life is inseparable from the problems to overcome this we need a rule that can prevent and impose sanctions on people who do things that are not in accordance with applicable norms or ethics. The law governing the protection of witnesses and victims as stated in the state sheet which is the Republic of Indonesia Law No. 31 of 2014 concerning Protection of Witnesses and Victims. During this time many criminal cases have never been touched by the legal process. The purpose of this thesis is finding out the legal protection of witnesses and reporters in revealing narcotics criminal acts by the Pekanbaru City Police and know the effort to overcome the legal protection barriers to witnesses and reporters in revealing criminal acts by the Pekanbaru City Police.

This type of research can be classified with research classified into sociological juridical research where the research examines the effectiveness of the law that is in force. From the research result, it is found that, first in protecting the rights of witnesses and victims, the government established an institution called the Witness and Victim Protection Agency (LPSK). Protection of witnesses and/or victims is declared to remain valid as long as it does not conflict with Article 44 of Law Number 13 year 2006 concerning protection of witnesses and victims. Second, the obstacles that occur are physical and psychological threats as well as criminalization efforts againts witnesses and victims or their families that make them afraid to give testimony before the court.
\end{abstract}

\section{INTRODUCTION}

Indonesia is a state of law (Rechstaat) that upholds the law, the law is manifested in regulations in the form of laws and arranged systematically in certain codifications or compilations. The process of proving or convicting a criminal act that occurs must be based on applicable laws. In this increasingly advanced era, human life is inseparable from the problems to be faced and humans cannot avoid it. Many problems that arise as a result of human behavior who want to do something in accordance with their desires but violate the rules or norms that apply in social life. To overcome this we need a rule that can prevent and impose sanctions on people who do things that are not in accordance with applicable norms or ethics. The law is called the law which has the power to force humans to act in accordance with general provisions in social life in society. Provisions that can give a law to someone because it upsets the balance of public interest are legal provisions that apply at that time in social life and are not past legal provisions that are no longer valid or planned to be effective. In other words, the rules that apply are positive laws. Positive law that is often called ius constitutum is legal provisions that apply at a particular time, time and place. In accordance with its aim of achieving order for justice, the rule of law will develop in line with the development of the association of human life. One of the positive laws in the community is the law governing the protection of witnesses and victims as stated in the gazette which is the Republic of Indonesia State Law Number 31 of 2014 concerning Protection of Witnesses and Victims. 
The law regulates how the government is able to provide protection and guarantees to witnesses and victims for a crime. This needs to be done because witnesses and victims are important elements in the handling of criminal acts. Without witnesses or victims' statements, then a criminal act cannot be processed through the criminal justice system, so the problem will not be solved.

But in reality, so little protection provided by law enforcement officials to reporting witnesses in each region, especially the author's research area in the city of Pekanbaru seemed to contradict the contents of Law No. 31 of 2014 concerning Protection of Witnesses and Victims. During this time many criminal cases have never been touched by the legal process to be tried because none of the witnesses or victims dared to reveal it, while other evidence obtained by the investigator was very inadequate.

The threat of persecution, abduction of victims, witnesses or family members to murder is the main reason that makes them feel discouraged to be involved in giving testimony. As an example of the case I got, there was a report from the public about the occurrence of Narcotics Abuse cases. The case occurred in 2018 in the Pekanbaru Resort Police Resort area. In this case there are reporters who ask for protection of the police. This case originated from a report of a citizen with the initials "X" towards his neighbor who had the initials "Y", where the reporter reported the neighbor for drug abuse committed at his home with some of his colleagues.

After the report comes in, the neighbor who is now a suspect has given threats and terror to the complainant committed by one of the suspects 'colleagues in the form of a reporter' $s$ house often being stoned by unknown people and often receives telephone terror from unknown persons. The reporter also requests protection from the authorities, but the form of protection that can be given to the reporter is only the confidentiality of identity. Witnesses should have received protection as regulated by the rights of witnesses which are contained in Article 5 of Law 31 of 2014 concerning Protection of Witnesses and Victims.

This study is aimed 1) to find out the Legal Protection of Witnesses and Reporters in Disclosing Narcotics Cases by Pekanbaru City Police, 2) to find out what constitutes an obstacle to Legal Protection Against Witnesses and Reporters in Disclosing Narcotics Cases by Pekanbaru City Police, 3) to find out the efforts to overcome the barriers to Legal Protection Against Witnesses and Reporters in Disclosing Narcotics Cases by Pekanbaru City Police.

\section{RESEARCH METHODOLOGY}

\section{Research Place}

Polresta Pekanbaru was established in 1975. Polresta is a continuation of the Pekanbaru City Police Resort, which is based on Jl. Ahmad Yani No.11 Pekanbaru. In the North, the Pekanbaru police area is bordered by Siak Regency, in the south by Kampar, in the West with Kampar and in the East with Pelalawan Regency. The total area of Pekanbaru Polresta's legal territory reaches $632.26 \mathrm{~km} 2$ or the smallest of all the territorial units in Riau Regional Police. Pekanbaru Police were led by the Chief of Police and Wakapolresta, the Pekanbaru Police had the main task of maintaining security, public order and law enforcement in Pekanbaru City. In the Pekanbaru police district there are 11 police (Sector Police), including: Pekanbaru City Police, Coastal Police Sector, Tampan Police Sector, Bukit Raya Police Sector, Sukajadi Sector Police, Payung Sekaki Sector Police, Lima Puluh Sector Police, Sector Tassel Sector Police, Coastal Sector Police Sector, Tenayan Sector Police Sector and Port Area Police. Since 1975 the name POLTABES was changed to Polresta Pekanbaru on 30 September 2010. And on 14 April 2000 also the Polresta Pekanbaru had experienced a fire due to a short circuit electricity.

\section{Type of Research}

Based on the formulation of the problem and research objectives, the type of research used by sociological legal research is research on the effectiveness of existing laws. In This study uses the author's approach is a study of sociological law that is research that wants to see the correlation of law and society, so as to be able to reveal the effectiveness of the law in society 
and identify unwritten laws that apply to the community, so in this sociological law research that is examined initially is the data secondary, then followed by research on primary data in the field or the community.

\section{Data Collection Techniques}

The data collection techniques in this study are:

a. Interview, which is a data collection tool by asking questions directly to the parties concerned about the results of research.

Interview methods can also be distinguished in structured and non-structured interviews. The interview method that I use is a non-structured interview where the interviewer is free to ask a respondent something without being bound by a list of questions.

b. Literature study, which is a data collection tool that is carried out through written data using content analysis. based on literature literature that has a correlation with the problem being studied.

\section{Data Analysis}

Data analysis is a follow-up process data processing which is the work of a researcher that requires accuracy and optimal thinking power. After obtaining data both primary and secondary data, then the data is grouped according to the type of data. Data that has been collected and grouped will be analyzed qualitatively. Qualitative analysis is a way of research that produces descriptive data, in the sense of what is stated in writing.

The results of this data analysis are deductively concluded, that is, a way of thinking that draws a conclusion from a statement or general proposition becomes a statement or a specific proposition, from which various conclusions can be submitted for suggestions.

\section{FINDINGS AND DISCUSSIONS}

\section{Legal Protection of Witnesses and Reporters in Exposing Narcotics Crimes by Pekanbaru City Police}

Every community gets a lot of information about various crime incidents, both obtained from mass media and electronic media. These crime incidents did not cause much suffering or loss for the victims and also the victims' families. In order to provide security and comfort for the community in their activities, surely these crimes need to be addressed either through preemptive, preventive and refressive approaches, and all must be handled professionally and by a competent institution.

It is not uncommon to find someone who is suffering (physically, mentally, or materially) due to a crime that has befallen him, so that the victim hide or the victim refuses to file for compensation because it is feared that the process will become longer and protracted which can result in prolonged suffering.

In protecting the rights of witnesses and victims, the government established an institution called the Witness and Victim Protection Agency (LPSK). As mentioned earlier, this institution reports directly to the president. Requests that the rights of witnesses and victims be protected can be submitted to the LPSK. However, this request was not necessarily approved, because based on the provisions of Article 5 paragraph (2) of Law Number 13 on Witness and Victim Protection, the head of the LPSK conducted a study of a particular case and was stated in the LPSK decision.

Article 44 of Law Number 31 of 2014 concerning amendments to Law Number 13 of 2006 concerning Protection of Witnesses and Victims, states that at the time this law was enacted, legislation governing the protection of witnesses and / or victims was declared remains valid as long as it does not conflict with this law.

Thus the rights of victims and witnesses to obtain compensation, restitution and rehabilitation as stated in Article 32 of Law Number 26 of 2000 concerning Human Rights Courts and are deemed not to conflict with Law Number 31 of 2014 concerning Protection of 
Witnesses and Victims, even though in the law The law also regulates other matters as regulated in other laws and regulations that still apply.

\section{Obstacles in Legal Protection Against Witnesses and Reporters in Disclosing Narcotics Cases in the Pekanbaru City Police Jurisdiction}

The number of criminal cases, especially narcotics abuse which is not revealed and resolved causes physical and psychological threats as well as criminalization efforts against witnesses and victims or their families which makes them afraid to give testimony before the court. Until now this has not been a concern.

\section{Efforts Made by the Police to Overcome Obstacles in Providing Legal Protection for Witnesses and Reporters in Disclosing Narcotics Cases}

a. The budget

A budget is a written plan regarding the activities of an organization that is stated quantitatively for a certain period of time and generally expressed in units of money, but can also be expressed in units of goods / services. Budget is a management tool in achieving goals.

This is the obstacle for the police in carrying out their duties and functions. Law enforcement is very tight with the budget, because to enforce justice requires operational costs, with the aim of maximizing the process of investigation and investigation to find evidence so that someone these can be convicted if the evidence is fulfilled.

b. Provide a sense of security

The need for security must be seen in a broad sense, not limited to physical security, but also security related to psycholigics which relates to security guarantees, system stability that prevents people from fear, anxiety, worry and many other things. Protection of witnesses and victims is often always a problem in the legal world, this is due to the inactivity of the authorized institution in carrying out its duties and functions from the witness and victim protection agency. The police can provide witness and victim protection in terms of reporting and a temporary sense of security, meaning that the police protect reporter data and provide temporary protection from threats that endanger the witnesses and reporters.

\section{CONCLUSIONS}

1. The most basic form of legal protection provided by law enforcement officers and witness and victim protection agencies against narrators of criminal acts of narcotics misuse is to keep the identity of the reporter a secret so that it is not known by the perpetrators and also other syndicates. The guarantee of legal protection and security is expected to be a condition that allows the public to no longer be afraid to report a crime that is known to law enforcement because they are worried or afraid that their lives will be threatened by certain parties. The forms of protection provided by LPSK to witnesses and victims include physical and psychological protection in the form of security and escort, placement in a safe house, obtaining a new identity, medical assistance and giving testimony without being present directly in court, psycho-social rehabilitation assistance. Legal protection in the form of sentence relief, and witnesses and victims and reporters cannot be prosecuted. Fulfillment of witnesses' procedural rights in the form of assistance, obtaining translators, getting information on the progress of cases, reimbursing transportation costs, getting legal advice, temporary living expenses assistance to the protection deadline and others in accordance with the provisions of Article 5 of Law Number 31 of 2014 concerning Witness Protection and Victim.

2. Obstacles traversed by law enforcement officials include the lack of adequate facilities and infrastructure, and also the vast area of Indonesia which makes it difficult for LPSK to provide protection for witnesses and victims outside Jakarta, especially in remote areas, and 
limited witness protection institutions. and victims who are only in the center (Jakarta) who have not had representative offices in each region in Indonesia.

3. Efforts to overcome obstacles that are passed by law enforcement officials, among others, by conducting counseling to the public regarding guarantees for the legal protection of witnesses and victims as well as give a sense of security to witnesses and reporters who have the courage to report narcotics cases to the authorities.

\section{RECOMMENDATIONS}

1. It is expected that law enforcement and institutions related to legal protection of witnesses and reporters will further increase supervision and protection of witnesses and reporters. Carry out and carry out duties and authority in accordance with applicable law.

2. Opening LPSK representative offices in other areas to make it easier for witnesses outside Jakarta to apply for protection and make it easier for LPSK to provide protection to witnesses and victims who are outside Jakarta.

3. It is expected that law enforcers and institutions related to legal protection of witnesses and reporters must increase efforts for socialization or legal counseling to ensure a safe and peaceful community life, and prevent abuse of narcotic crime so that the number of users and narcotics victims are not increasing or growing.

\section{REFERENCES}

Arief, Barda Nawawi. (2002). Bunga Rampai Kebijakan Hukum Pidana. Bandung. PT. Citra Aditya Bakti.

Ashshofa, Burhan. (2013). MetodePenelitianHukum. Jakarta. Rineka Cipta.

Ali, Zainudin. (2013). Metode Penelitian Hukum Edisi 1 Cetakanke 4, Jakarta. Sinar Grafika. Djamil, R. Abdoel. (1993). Pengantar Hukum Indonesia (Edisi Revisi). Jakarta. Raja Grafindo Persada.

Hamzah, Andi. (2001). Asas-Asas Hukum Pidana. Jakarta. RinekaCipta HR, Ridwan. (2010). Hukum Administrasi Negara. Jakarta. Rajawali Pers

Iksan, Muhammad. ( 2009). Hukum Perlindungan Saksi Dalam Sistem Peradilan Pidana Indonesia. Surakarta. Muhammadiyah Pers.

Jaya, Nyoman Serikat Putera (2004). Telaahan Akademik Yurisprudensi Tentang Pelanggaran HAM Berat (Putusan Pengadilan HAM Ad Hoc Pada Pengadilan Negeri Jakarta Pusat), BPHN Departemen Kehakiman Dan HAM RI, Jakarta.

Kadir, Abdul. (2006). Etika Profesi Hukum. Bandung. Citra Aditya Bakti. 